Buletin JSJ, 2 (2), 2020, 83-92

Available online di: http://ejournal-balitbang.kkp.go.id/index.php/JSJ/index

\title{
ASPEK BIOLOGI RAJUNGAN (Portunus pelagicus) DI TELUK BANTEN, INDONESIA
}

\section{BIOLOGICAL ASPECT OF THE SWIMMING CRABS (Portunus pelagicus) IN BANTEN BAY, INDONESIA}

\author{
M.F. Mursyid ${ }^{1}$, P.A. Prabowo ${ }^{1}$, I.P. Sudrajat ${ }^{1}$, D. Puspa ${ }^{1}$, N. Farhandika ${ }^{1}$, A.Z.A. Mourniaty ${ }^{1}$, \\ R. Suharti ${ }^{1,2}$, Kadarusman ${ }^{1,2}$, dan Heri Triyono ${ }^{1,2}$ \\ ${ }^{1}$ Bioecology Public Awareness and Education Campaigns, Prodi Teknologi Pengelolaan Sumberdaya Perairan, \\ Sekolah Tinggi Perikanan (STP), Jalan AUP, Pasar Minggu, Jakarta 12520. \\ ${ }^{2)}$ Laboratorium Biologi dan Konservasi (BIOVASI), Kelompok Keilmuan Dosen (KKD) Pengelolaan Sumberdaya \\ Perairan, Subrumpun Ilmu Biologi dan Konservasi, Sekolah Tinggi Perikanan.
}

Email: fadilmursyid135@gmail.com

\begin{abstract}
ABSTRAK
Rajungan (Portunus pelagicus) merupakan salah satu sumberdaya perikanan yang penting di wilayah Perairan Teluk Banten. dan minim informasi mengenai populasi dan status stok. Tujuan penelitian ini adalah mengkaji Aspek biologi rajungan (Portunus pelagicus) di Perairan Teluk Banten, penelitian ini dilakukan pada bulan Maret sampai April 2019. Penelitian ini menggunakan metode market survey (Observasi pada pengepul rajungan) dan data langsung di lapangan sebagai data primer serta data sekunder. Aspek biologi rajungan yang diamati meliputi lebar bobot, dan jenis kelamin. Hasil penelitian diharapkan dapat memberikan informasi mengenai perikanan rajungan dalam pengelolaan berkelanjutan sumberdaya rajungan di Perairan Teluk Banten. Hasil analisa jumlah stok hasil tangkapan rajungan di teluk banten berjumlah 476 (302 jantan dan 174 betina), Untuk hasi I analisa ukuran pertama kali tertangkap (Lc) diperoleh nilai Lc jantan $=10,47 \mathrm{~cm}$ dan $\mathrm{Lc}$ betina $13,50 \mathrm{~cm}$, Hasil analisa hubungan lebar-bobot diperoleh nilai $\mathrm{b}$ jantan $=11.7810$ (allometrik positif), sedangkan b betina $=10,6747$ (allometrik positif), Ukuran pertama kali matang gonad (Lm) jantan sebesar 11,82 cm dan betina 9,30 cm, Perbandingan sex ratio sebesar 1,73:1 lebih dominan rajungan jantan.
\end{abstract}

Kata Kunci : Rajungan, Lebar Bobot, Nisbah Kelamin dan Teluk Banten.

\begin{abstract}
Rajungan (Portunus pelagicus) is one of the important fisheries resources in the Banten Bay Waters region. and minimal information about the population and stock status. The purpose of this study was to examine the biological aspects (Portunus pelagicus) based on the rate of exploitation and the potential ratio of spawning in the waters of Banten Bay, this study was conducted in March until April 2019. This study used the market survey method (Observation of Rajungan collectors) and direct data in the field as primary data and secondary data. The biological aspects observed include width weight and sex ratio. The results of the study are expected to provide information about the crab fisheries in sustainable management of crab resources in the waters of the bay of Banten. The results of the analysis of the number of fish stocks caught in the bay of Banten were 476 (302 men and 174 females). For the results of the first captured size analysis $(L C)$ the male $L C=10.47 \mathrm{~cm}$ and $L c 13.50$ $\mathrm{cm}$ were obtained, the result of a wide-relationship analysis weight is obtained for male $b$ value $=$ 11.7810 (positive allometric), while $b$ female $=10.6747$ (positive allometric), first size mature male gonad $(\mathrm{Lm})$ is $11.82 \mathrm{~cm}$ and female $9.30 \mathrm{~cm}$, sex ratio is 1.73: 1 is more dominant male crab.
\end{abstract}

Keywords: Crab, Width Weights, Sex Ratio, and Teluk Banten. 
Buletin JSJ, 2 (2), 2020, 83-92

Available online di: http://ejournal-balitbang.kkp.go.id/index.php/JSJ/index

\section{PENDAHULUAN}

Indonesia memiliki keanekaragaman hayati laut yang sangat tinggi dan dapat dimanfaatkan sebagai bahan pangan dan bahan industri (Santoso, 2016). Rajungan (Portunus pelagicus) banyak ditemukan di beberapa perairan lepas pantai dan lautan indo-pasifik (Susanto, 2007). Sampai saat ini rajungan (Portunus pelagicus) masih merupakan komoditas laut yang mempunyai nilai ekonomis yang penting (Djunaedi, 2009). Produksi rajungan Indonesia mayoritas berasal dari perairan utara Jawa yang memiliki kontribusi sebesar $28 \%$ (Kembaren \& Ernawati, 2012). Produksi rajungan di Indonesia 60\% diekspor ke Amerika sedangkan sisanya diekspor ke beberapa negara tujuan ekspor lainnya seperti Singapura, Jepang, Belanda dan Eropa (Linggarjati, 2013).

Perairan Teluk Banten memiliki potensi sumberdaya perikanan dan kelautan yang masih tinggi. Potensi perikanan dan kelautan telah dimanfaatkan untuk berbagai macam kegiatan pembangunan nasional serta mensejahterakan kehidupan nelayan (Triaso, 2012), dan memaksimalkan produksi perikanan yang berkesinambungan (Setiyowati, 2016). Salah satu potensi sumberdaya perikanan tersebut adalah rajungan yang merupakan komoditas perikanan dengan nilai ekonomis penting (Kembaren dan Surahman, 2018). Pangsa pasar rajungan yang dominan adalah ekspor dalam bentuk daging yang dikalengkan. Ekspor rajungan Indonesia pada tahun 2014 mencapai 20.8 juta ton senilai 108 trilliun rupiah (Anam, 2019). Upaya budidaya rajungan telah banyak dilakukan, tetapi benih masih tergantung pada alam (Ernawati, 2014).

Rajungan merupakan salah satu jenis Crustracea yang populer di masyarakat dan keberadaannya hampir tersebar di seluruh Perairan Indonesia (Yusfiandayani \& Sobari, 2011). Rajungan (Portunus pelagicus) termasuk dalam kelas Crustasea, famili Portunidae yang penyebarannya meliputi lautan Indo-Pasifik (Tirtadanu \& Suman, 2018). Rajungan (Portunus pelagicus) merupakan salah satu jenis rajungan yang paling sering ditangkap oleh nelayan di Indonesia (Arif et al., 2019). Tingginya harga rajungan dipasaran berdampak pada peningkatan penangkapan rajungan (Fahrun et al., 2016). Hewan ini menjadi komoditas ekspor urutan ketiga dalam jumlah setelah udang dan ikan (Puspito, 2011). Volume ekspor rajungan di Indonesia mengalami peningkatan dari tahun 2014 sampai tahun 2016 yaitu 10,8 juta ton menjadi 19,4 juta ton (Edi, Djunaedi, \& Redjeki, 2018). Kebiasaan makan di alam tergolong karnivora dengan memakan biota bentik invertebrata yang pergerakkannya pelan dan sesil (Prihatiningsih \& Wagiyo, 2017). Tingginya nilai jual rajungan mendorong peningkatan upaya penangkapan (Ernawati et al., 2014).

Secara umum Rajungan (Portunus pelagicus) memegang peranan penting dalam stabilitas ekologi dan sosial-ekonomi. Secara ekologi rajungan berperan penting sebagai biota yang menjaga keseimbangan ekologi di perairan pesisir (Erlinda, Sara, \& Irawati, 2016). Rajungan di Indonesia sampai sekarang masih merupakan komoditas perikanan yang memiliki nilai ekonomis tinggi. Sampai saat ini seluruh kebutuhan ekspor rajungan masih mengandalkan dari hasil tangkapan di laut (Jafar, 2011). Rajungan hidup sebagai binatang dewasa di daerah estuaria dan di teluk pantai. Rajungan (Portunus pelagicus) banyak ditemukan di beberapa perairan lepas pantai dan lautan Indo-pasifik (Jafar, 2011). Di Indonesia rajungan banyak terdapat di daerah mangrove seperti di kabupaten Cilacap, pantai Gilimanuk, pantai Muncar, pantai Pasuruan, Lampung, Medan dan Kalimantan Barat (Susanto, 2007).

Tekanan upaya penangkapan yang terus meningkat menyebabkan hasil tangkapan per upaya yang diperoleh semakin sedikit (Ernawati et al., 2014). aktivitas penangkapan rajungan semakin intensif dan tidak terkendali yang mengarah kepada kerusakan populasi rajungan di alam (Pirzan, 2011). Kondisi seperti ini dapat memberikan tekanan besar pada populasi rajungan seperti ditunjukan jumlah hasil tangkapan yang terus berkurang, ukuran 
Buletin JSJ, 2 (2), 2020, 83-92

Available online di: http://ejournal-balitbang.kkp.go.id/index.php/JSJ/index

tubuh rajungan lebih kecil dan fishing ground semakin jauh (Sains \& Sara, 2019). Pada pengelolaan perikanan rajungan yang berkelanjutan diperlukan informasi biologis maupun data hasil tangkapan. Informasi yang diperoleh diolah ke dalam bentuk informasi yang berguna untuk membuat kebijakan pengelolaan, penetapan serta memantau pelaksanaan kebijakan pengelolaan tersebut (Pristya, 2015). Penelitian ini bertujuan untuk mengkaji aspek biologi rajungan di perairan Teluk Banten.

\section{METODE PENELITIAN}

Penelitian dilaksanakan di Teluk Banten pada tanggal 6 Maret sampai 16 April 2019 di empat lokasi yaitu Desa Terate, Desa Domas, dan Karangantu. Sampel sebanyak 476 ekor rajungan (302 jantan dan 174 betina). Dengan metode pengambilan data langsung sebagai data primer dan sekunder. Stasiun pengamatan disajikan pada Gambar 1.

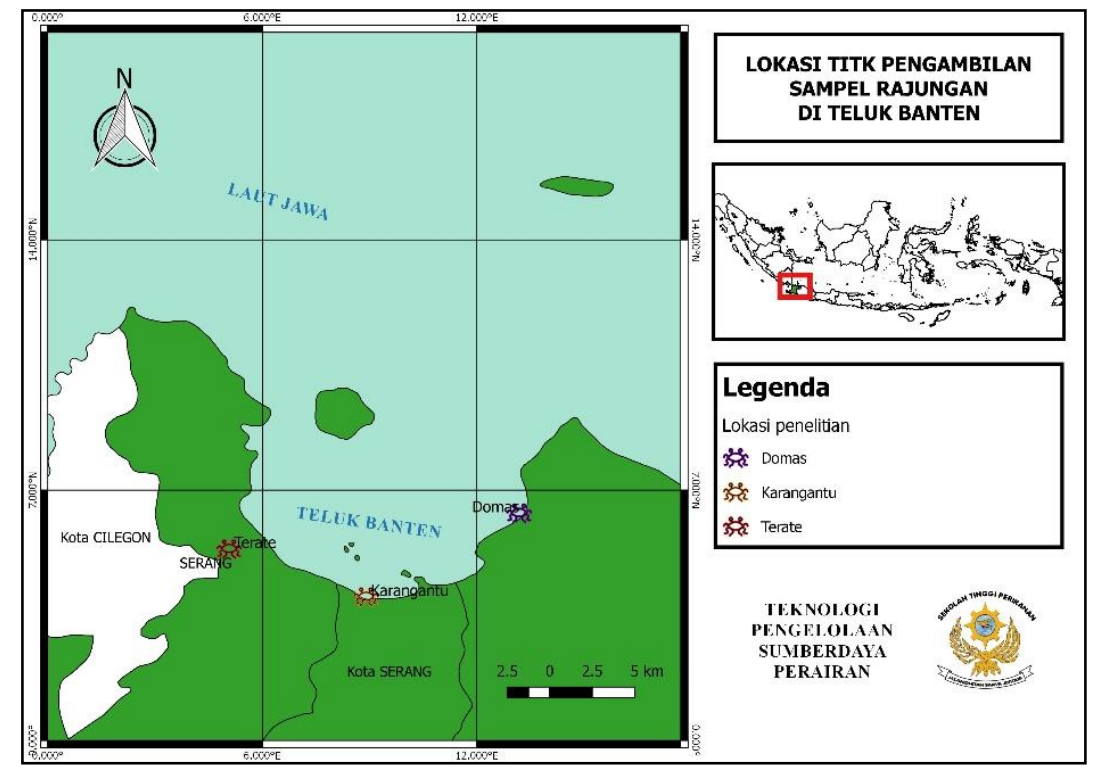

Gambar 1. Stasiun Pengamatan.

Analisis meliputi: hubungan lebar-berat; sex ratio (perbandingan jenis kelamin); Ukuran pertama kali tertangkap (Length at first capture/Lc) yang diperoleh dengan memplotkan presentase frekuensi kumulatif rajungan yang tertangkap dengan ukuran lebar totalnya (Ningrum et al. 2015); dan Ukuran pertama kali matang gonad (Length at first maturity/Lm) yaitu tahap pada suatu siklus hidup yang telah mencapai bentuk dewasa dan mampu bereproduksi (Soedharma 2012).

Analisis yang digunakan dalam menduga hubungan lebar dan bobot merupakan hubungan eksponensial dengan persamaan sebagai berikut (Effendie, 1979 dalam Oktaviyani, 2013):

$$
\boldsymbol{W}=\boldsymbol{a} \boldsymbol{L}^{\boldsymbol{b}}
$$

dengan:

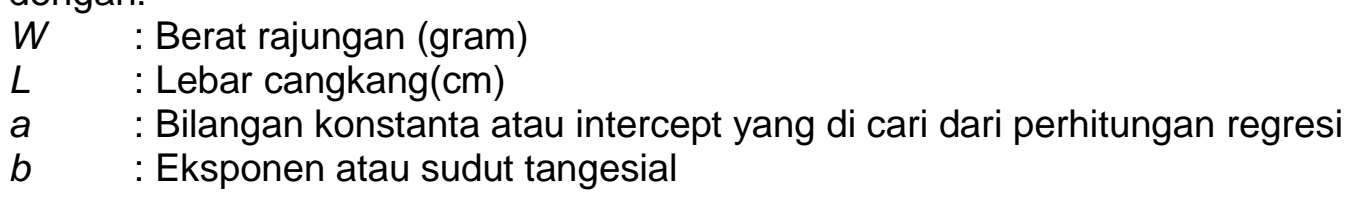


Buletin JSJ, 2 (2), 2020, 83-92

Available online di: http://ejournal-balitbang.kkp.go.id/index.php/JSJ/index

Analisis nisbah kelamin (sex ratio) untuk mengetahui hubungan jantan-betina dari suatu populasi ikan maupun pemijahannya maka pengamatan mengenai nisbah kelamin (sex ratio) ikan yang diteliti merupakan salah satu faktor yang amat penting. Selanjutnya, untuk mempertahankan kelestarian ikan yang diteliti diharapkan perbandingan ikan jantan dan betina seimbang ( $1: 1)$. Nisbah kelamin jantan dan betina dapat dilakukan melalui pengujian dan uji ' $X^{2}$ ' (chi square) dengan rumus menurut Effendie (1979):

$$
X^{2}=\frac{(f o-f h)^{2}}{f h}
$$

Dengan:

$X^{2} \quad$ : chi square

$f_{0} \quad$ : frekuensi biota yang diamati

$f_{h} \quad$ : frekuensi biota yang diharapkan

Perhitungan panjang ikan pertama kali matang gonad (Lm) menggunakan persamaan Spearman-Karber yang dikembangkan oleh Udupa (1986) :

$$
\mathbf{m}=\mathbf{x}_{\mathbf{k}}+\frac{\mathbf{x}}{2}-\left(\mathbf{x} \sum \mathbf{P i}\right.
$$

Dengan :

$m \quad$ : logaritma dari kelas panjang pada kematangan pertama

$X \quad$ : selisih logaritma dari pertambahan nilai tengah panjang

$k \quad$ : jumlah kelas panjang

$x_{k} \quad$ : logaritma nilai tengah panjang ikan yang telah matang gonad $\left(\mathrm{P}_{\mathrm{i}}=1\right)$

meng-antilogkan persamaan di atas, maka didapat ukuran pertama kali matang gonad $\left(\mathrm{L}_{\mathrm{m}}\right)$

Pendugaan ukuran rajungan pertama kali tertangkap dilakukan dengan mengukur lebar karapas yang telah dikelompokkan berdasarkan kelas panjang total (sumbu $\mathrm{x}$ ). Dengan jumlah rajungan yang telah dinyatakan dalam persentase komulatif (sumbu y), dihitung dengan kurva logistik (kurva S). Untuk memperoleh nilai Lc (Length at first capture) yaitu dengan persentase sebesar $\mathrm{L} 50 \%$ artinya lebar dimana $50 \%$ dari rajungan tertahan .

Dengan:

$$
\begin{gathered}
\text { SL }=\frac{1}{1+\exp (\mathbf{S 1}-\mathbf{S 2} * \mathbf{L})} \\
\mathbf{L} \mathbf{5 0} \%=\frac{\mathbf{S 1}}{\mathbf{S 2}}
\end{gathered}
$$

$S L \quad$ : Kurva Logistik; $\mathrm{S}_{1}=\mathrm{a}, \mathrm{S}_{2}=\mathrm{b}$

$S_{1}$ dan $S_{2}$ : Konstanta pada rumus kurva logistik

\section{HASIL DAN PEMBAHASAN}

Rajungan (Portunus pelagicus) yang tertangkap di Teluk Banten mayoritas jantan berukuran lebar karapas 11-12 cm (Gambar 2), sedangkan untuk mayoritas betina berukuran lebar karapas $13-14 \mathrm{~cm}$. Pada penelitian ini sampel berjumlah 476 (302 Jantan dan 174 Betina), diperoleh kisaran lebar karapas rajungan yang tertangkap jantan antara $5.1-17.7 \mathrm{~cm}$ dengan rata-rata $11.65 \mathrm{~cm}$ dan betina $5-16.3 \mathrm{~cm}$ dengan rata-rata $11.73 \mathrm{~cm}$. Rata-rata ukuran rajungan pada penelitian ini lebih kecil dibandingkan dengan yang diperoleh di perairan Pati (pantai utara Jawa) yaitu jantan $12,33 \mathrm{~cm}$ dan betina $12,48 \mathrm{~cm}$ (Ernawati, 2013). Analisis hubungan lebar karapas dengan berat rajungan digunakan data lebar 
Buletin JSJ, 2 (2), 2020, 83-92

Available online di: http://ejournal-balitbang.kkp.go.id/index.php/JSJ/index

karapas rajungan dan berat rajungan untuk melihat pola pertumbuhan rajungan. Oleh karena itu bobot dapat dianggap sebagai fungsi dari lebar (Effendie, 2002). Frekuensi lebar rajungan disajikan pada Gambar 2.

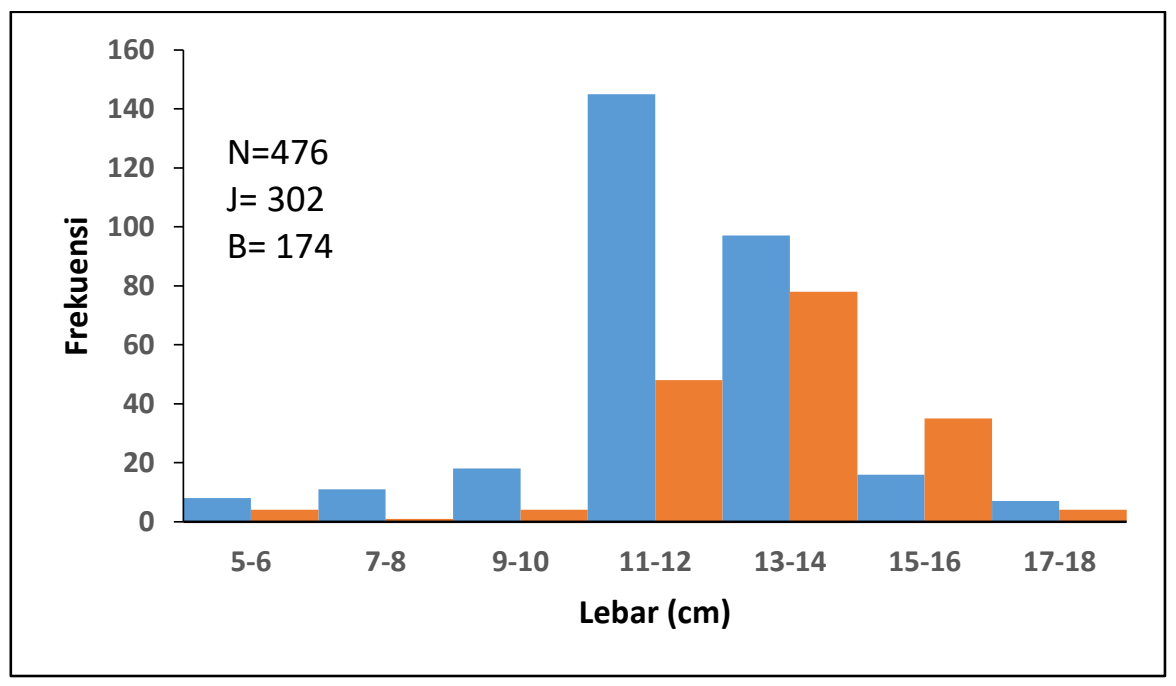

Gambar 2. Frekuensi Lebar Rajungan.

\section{Hubungan Lebar dan Bobot Rajungan}

Berdasarkan analisis hubungan lebar karapas dengan berat rajungan, diperoleh nilai berat jantan $=11.7810$ (pertumbuhan berat rajungan lebih cepat dari pada lebar rajungan tersebut atau allometrik positif) sedangkan berat betina $=10.6747$ (pertumbuhan berat rajungan lebih cepat dari pada lebar karapas rajungan tersebut atau allometrik positif) (Gambar 3). Sementara pada penelitian di perairan Tegal, Jawa Tengah rajungan jantan mengalami pertumbuhan allometrik positif dengan nilai $b=3,39$ dan rajungan betina mengalami pertumbuhan allometrik negative dengan nilai $b=2,91$. pertumbuhan rajungan juga dapat dilihat dengan mengetahui hubungan panjang (lebar)-berat. Melalui hubungan ini dapat digambarkan kecepatan pertumbuhan panjang (lebar) terhadap pertumbuhan bobot (Pauly, 1984). Persamaan hubungan lebar dan bobot rajungan pada Gambar 3.

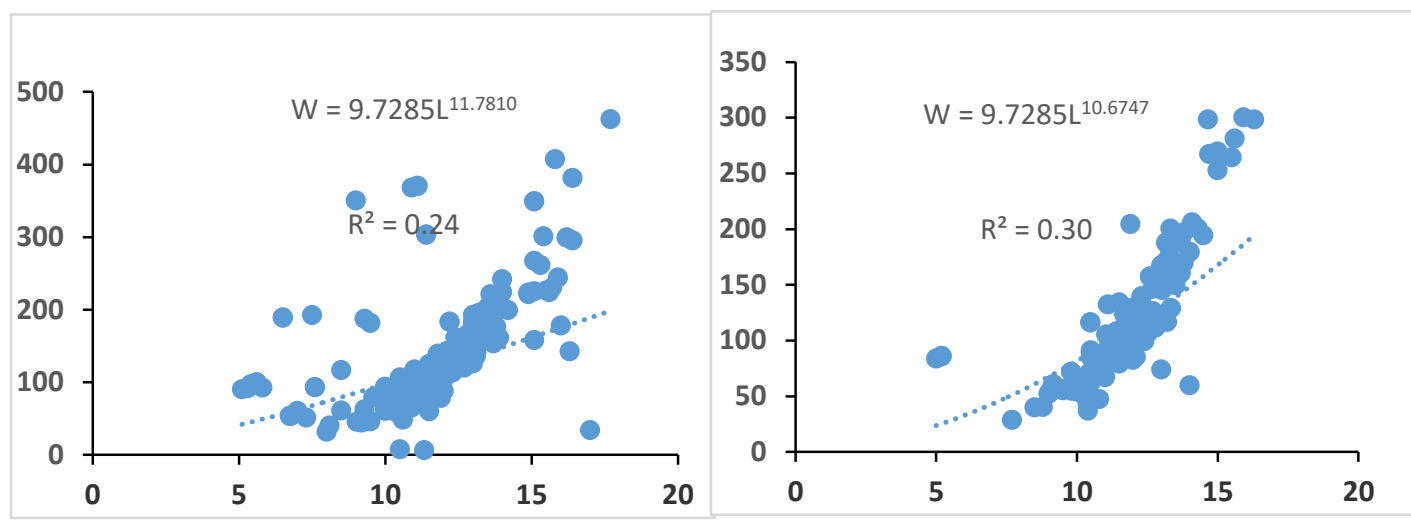

a. Jantan

b. Betina

Gambar 3. Hubungan Lebar-Bobot Rajungan. 
Buletin JSJ, 2 (2), 2020, 83-92

Available online di: http://ejournal-balitbang.kkp.go.id/index.php/JSJ/index

\section{Nisbah Kelamin}

Hasil penelitian menunjukkan bahwa populasi rajungan di Teluk Banten dalam kondisi lebih dominan jantan dengan perbandingan jantan betina 2:1 (Tabel 1). Nisbah kelamin ideal rajungan berkisar 1:1 (Pristya et al., 2015). dibutuhkan 1 jantan untuk membuahi 1 betina. Dalam penelitian Perbandingan nisbah kelamin jantan dan betina sebesar 1,24:1 (Fauzi et al., 2018). Menunjukkan bahwa jumlah populasi rajungan jantan mengalami peningkatan dan yang ideal untuk perbandingan jenis kelaminnya (Suryakomara, 2013), komposisi nisbah kelamin akan mengikuti perubahan musim pemijahan (Hill et al., 1982). Rajungan betina sebelum memijah tidak menetap di perairan pantai sehingga dapat menyebabkan rajungan betina tidak mudah tertangkap dibandingkan jantan (Potter dan de Lestang, 2000), ada juga yang menyatakan bahwa rajungan betina cenderung memilih substrat yang berpasir selama musim pemijahan sehingga rajungan betina pergi ke daerah yang berpasir, hal ini menyebabkan hasil tangkapan cenderung jantan menurut (Sumpton et al. 1994).

Tabel 1. Nisbah Kelamin Rajungan

\begin{tabular}{|c|c|c|c|c|c|c|c|}
\hline Sampel & $f_{0}$ & $f_{h}$ & $f_{o}-f_{h}$ & $\left(f_{0}-f_{h}\right)^{2}$ & $(f o-f h)^{2} / f h$ & $\sum\left(\mathbf{f}_{0}-\mathbf{f}_{h}\right)^{2} / \mathfrak{f}_{h}$ & $x^{2}$ tabel \\
\hline Jantan & 302 & 238 & 64 & 4096 & 17.210 & \multirow{2}{*}{34.420} & \multirow{2}{*}{7.88} \\
\hline Betina & 174 & 238 & -64 & 4096 & 17.210 & & \\
\hline
\end{tabular}

\section{Ukuran Pertama Kali Tertangkap}

Rajungan yang tertangkap di perairan Teluk Banten mempunyai lebar karapas antara 5 $17.7 \mathrm{~cm}$ dengan modus pada kelas $12-13 \mathrm{~cm}$. Rajungan jantan dan betina dominan tertangkap masing-masing pada lebar karapas antara $11-12 \mathrm{~cm}(11,72 \pm 1,82)$ untuk jantan dan $12-13 \mathrm{~cm}(11,65 \pm 2,04)$ untuk betina. Distribusi frekuensi lebar karapas rajungan disertakan pada (Gambar 2). Ukuran rajungan pertama kali tertangkap (Lc) dan ukuran pertama kali matang gonad $(\mathrm{Lm})$ dinyatakan dalam proporsi $50 \%$ dari populasi yang diamati. Nilai Lc dan Lm ini diperoleh dengan menggunakan fungsi logistik (Gambar 4).

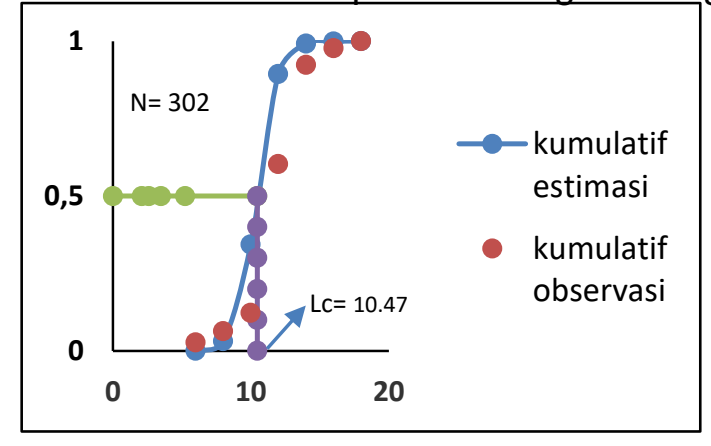

a. Jantan

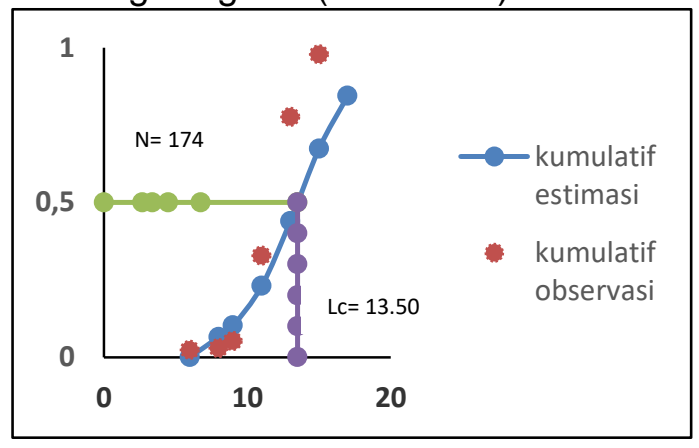

b. Betina

Gambar 4. Ukuran rata-rata tertangkap (Lc) Rajungan.

Diperoleh nilai Lc jantan 10.47 dan Lc betina 13.50, ukuran pertama kali matang gonad (Lm) di perairan Teluk Banten rajungan jantan sebesar 11,82 cm dan rajungan betina sebesar $9,30 \mathrm{~cm}$, dapat disimpulkan bahwasanya $\mathrm{Lc}>\mathrm{Lm}$, dimana rajungan yang tertangkap sudah sempat memijah terlebih dahulu. Sedangkan untuk rajungan betina Lc > Lm, dimana rajungan betina yang tertangkap telah melakukan memijah sebelumnya. Hal ini mengindikasikan rajungan jantan lebih cepat mengalami penurunan populasi dibandingkan rajungan betina, yang dapat menyebabkan growth overfishing (mengakibatkan hilangnya 
Buletin JSJ, 2 (2), 2020, 83-92

Available online di: http://ejournal-balitbang.kkp.go.id/index.php/JSJ/index

populasi sementara dan perubahan rantai makanan). perpaduan faktor genetik dan lingkungan akan memberikan variasi umur dan ukuran untuk mencapai tingkat kematangan gonad (Pasisingi, 2011). Sedangkan kematangan seksual dipengaruhi oleh hormon, faktor lingkungan dan makanan (Atmadja, 1994).

\section{KESIMPULAN}

Dari penelitian yang telah dilakukan dapat disimpulkan bahwa hubungan lebar-berat bersifat allometrik positif. Perbandingan jantan dan betina menunjukkan bahwa nilai jantan lebih dominan daripada betina dengan perbandingan 2:1. Nilai Lc = Jantan 10,47 cm; betina 13,50 $\mathrm{cm}$ dan nilai $\mathrm{Lm}=$ Jantan $11,82 \mathrm{~cm}$; betina 9,30 cm. Populasi rajungan jantan lebih cepat mengalami penurunan dibandingkan betina. Jika dalam jangka panjang kondisi penangkapan ini terus terjadi akan menyebabkan growth overfishing yang mengakibatkan hilangnya populasi sementara dan perubahan rantai makanan.

\section{UCAPAN TERIMA KASIH}

Terima kasih kami ucapkan kepada DKP Provinsi Banten, DKP Kabupaten Serang, DKP Kota Serang, PPN Karangantu dan PSDKP Serang atas bantuan yang diberikan selama dalam penelitian. Ucapan terima kasih juga kami sampaikan kepada civitas akademika Kampus BAPPL-STP Serang dan STP Jakarta, masyarakat Desa Domas, Desa Karangantu serta pihak lainnya yang tidak bisa disebutkan satu persatu.

\section{DAFTAR PUSTAKA}

Anam, A., Redjeki, S., \& Hartati, R. (2019). Sebaran Ukuran Lebar Karapas Dan Berat Rajungan (Portunus pelagicus) Di Perairan Betahwalang Demak. Journal of Marine Research, 7(4), 239-247.

Apriliyanto.H, Pramonowibowo, \& Yulianto. T. (2014). Analisis Daerah Penangkapan Rajungan Dengan Jaring Insang Dasar (Bottom Gillnet) Di Perairan Betahwalang, Demak. Journal Of Fisheries Resources Utilization Management And Technology, 3(3), 71-79. Retrieved From Http:/Www.Ejournal-S1.Undip.Ac.Id/Index.Php/Jfrumt

Arif, M. (2019). Hubungan antar ukuran beberapa bagian tubuh rajungan (portunus pelagicus) di perairan utara lamongan, jawa timur.

Arios, A. H., Solichin, A., \& Saputra, W. S. (2013). Hasil Tangkapan Rajungan ( Portunus pelagicus ) dengan Menggunakan Alat Tangkap Bubu Lipat yang Didaratkan di TPI Tanjung Sari Kabupaten Rembang, 2, 243-248.

Arshad, Efrizal, M. S. Kamarudin, C. R. S. (2006). Study On Fecundity , Embryology And Larval Development Of Blue Swimming Crab Portunus Pelagicus ( Linnaeus , 1758 ) Under Laboratory Conditions. Research Journal Of Fisheries And Hydrobiology, 1(1), 35-44.

Atmadja Sb. 1994. Tingkat Kematangan Gonad Beberapa Ikan Pelagis Kecil. Jurnal Penelitian Perikanan Indonesia. 3(2):83-89.

Aulia, M. (2018). Patogenesis dan Gejala Klinis Rajungan ( Portunus pelagicus). Yayasan borneo lestari

Bahri Agus, S., Zulbainarni, N., Sunuddin, A., Subarno, T., Hikmat Nugraha, A., Rahimah, I., ... Jihad, . (2017). Spatial Distribution Of Blue Swimmer Crab (Portunus Pelagicus) During Southeast Monsoon In Lancang Island, Kepulauan Seribu. Jurnal IImu Pertanian 
Buletin JSJ, 2 (2), 2020, 83-92

Available online di: http://ejournal-balitbang.kkp.go.id/index.php/JSJ/index

Indonesia, 21(3), 209-218. Https://Doi.Org/10.18343/Jipi.21.3.209.

Bajomulyo, D. I. P. P. P. (2016). Komposisi Tangkapan Cantrang Dan Aspek Biologi Ikan Beloso (Saurida Tumbill) Di Ppp Bajomulyo, Juwana Http://EjournalS1.Undip.Ac.Id/Index.Php/Maquares, 5(02), 17-26.

Budiaryani, N. R. (2007). Kajian Perikanan Rajungan Di Perairan Semarang. Balai Besar Pengembangan Penangkapan lkan. Semarang.

Damora, A. (2011). Beberapaaspekbiologi Ikanbeloso (Sauridamicropectoralis) Di Perairan Utara Jawa Tengah, 3(6), 363-367.

Damora, A., \& Nurdin, E. (2016). Beberapa Aspek Biologi Rajungan ( Portunus Pelagicus ) Di Perairan Labuhan Maringgai , Lampung Timur Biological Aspects Of Blue Swimming Crab ( Portunus Pelagicus ) In Labuhan Maringgai , East Lampung, 8(April), 13-20.

Djunaedi, A. (2009). Kelulushidupan dan Pertumbuhan Crablet Rajungan (Portunus pelagicus Linn.) pada Budidaya dengan Substrat Dasar yang Berbeda. ILMU KELAUTAN: Indonesian Journal of Marine Sciences, 14(1), 23-26.

Edi, H. S. W., Djunaedi, A., \& Redjeki, S. (2018). Beberapa Aspek Biologi Reproduksi Rajungan (Portunus pelagicus) di Perairan Betahwalang Demak. Jurnal Kelautan Tropis, 21(1), 55. https://doi.org/10.14710/jkt.v21i1.2409

Erlinda, S., Sara, L., \& Irawati, N. (2016). Makanan Rajungan ( Portunus Pelagicus ) Di Perairan Lakara Kabupaten Konawe Selatan , Sulawesi Tenggara [ Food Of The Blue Swimming Crab ( Portunus Pelagicus ) In Lakara Waters Of. Jurnal Manajemen Sumber Daya Perairan, 1(2), 131-140.

Ernawati, T., Mennofatria, B., \& Yonvitner. (2014). Biologi Populasi Rajungan (Portunus Pelagicus) Di Perairan Sekitar Wilayah Pati, Jawa Tengah. Bawal, 6(1), 31-40.

Fauzi, M. J., Gaffar, A., Erdyanto, B., Dhewang, I. B., Arafat, M. A., Akmalia, D. A., \& Triyono, H. (2018). Pendugaan Growth Overfishing Rajungan (Portunnus Pelagicus) Di Teluk Banten. Jurnal Perikanan Dan Kelautan, 8(1), 96-103

Hamid, A., Wardiatno, Y., Batu, D. T. F. L., \& Riani, E. (2015). Fekunditas Dan Tingkat Kematangan Gonad Rajungan (Portunus Pelagicus) Betina Mengerami Telur Di Teluk Lasongko, Sulawesi Tenggara. Bawal Widya Riset Perikanan Tangkap, 7(1), 43. Https://Doi.Org/10.15578/Bawal.7.1.2015.43-50.

Hamid, A., Wardiatno, Y., Batu, D. T. L., \& Riani, E. (2016). Distribusi Ukuran SpasialTemporal Dan Berdasarkan Tingkat Kematangan Gonad Rajungan (Portunus Pelagicus Linnaeus 1758) Di Teluk Lasongko, Buton Tengah, Sulawesi Tenggara. Omni-Akuatika, 12(2).

Ihsan, I., \& Saenong, M. (2019). Pemetaan Spasial Distribusi Dan Sebaran Rajungan (Portunus Pelagicus) Berbasarkan Siklus Hidup Di Perairan Pantai Kabupaten Pangkep. Prosiding Seminakel, 1(1).

Jafar, L. (2011). Perikanan Rajungan Di Desa Mattiro Bombang (Pulau Salemo, Sabangko Dan Sagara) Kabupaten Pangkep. Program Studi Manajemen Sumberdaya Perairan Jurusan Perikanan Fakultas IImu Kelautan Dan Perikanan Universitas Hasanuddin Makassar.

Kembaren, D., \& Ernawati, T. S. (2012). Biology And Population Parameters Of Blue Swimming Crab ( Portunus Pelagicus ) In The Bone Bay And Adjacent Waters. Jurnal Penelitian Perikanan Indonesia, 273-281. Https://Doi.Org/10.15578/Jppi.18.4.2012.273-281 
Buletin JSJ, 2 (2), 2020, 83-92

Available online di: http://ejournal-balitbang.kkp.go.id/index.php/JSJ/index

King, M. 1995. Fisheries Biology, Assessment And Management. United Kingdom: Fishing News Books. 341 P.

Linggarjati, K. F., Djunaedi, A., \& Subagiyo, S. (2013). Uji Penggunaan Bacillus sp. sebagai Kandidat Probiotik Untuk Pemeliharaan Rajungan (Portunus sp.). Journal of Marine Research, 2(1), 1-6. Retrieved from https://ejournal3.undip.ac.id/index.php/jmr/article/view/2048.

Muhsoni, F. F., \& Abida, I. W. (2009). Analisis Potensi Rajungan (Portunus Pelagicus) Di Perairan Bangkalan-Madura. Embryo, 6(2), 140-147.

Ngurah, Wiadnyana. N. (2017). Lamongan District, East Java. Prosiding Simposium Nasional Krustasea 2017, 147.

Ningrum, V. P., Ghofar, A., \& Ain, C. (2015). Beberapa Aspek Biologi Perikanan Rajungan (Portunus Pelagicus) Di Perairan Betahwalang Dan Sekitarnya.

Nurlaila Ervina Herliany, Z. (2015). Hubungan Lebar Karapas Dan Berat Kepiting Bakau ( Scylla Spp ) Hasil Tangkapan Di Desa Kahyapu Pulau Enggano. Jurnal Kelautan, 8(2), 89-94.

Palupi, R. D. (2018). Komposisi Ukuran Kepiting Rajungan (Portunus Pelagicus) Berdasarkan Fase Bulan Di Perairan Lakara, Konawe Selatan, Sulawesi Tenggara. Jurnal Manajemen Sumber Daya Perairan, 1(3).

Pasisingi N. 2011. Model Produksi Surplus Untuk Pengelolaan Sumberdaya Rajungan (Portunus Pelagicus) Di Teluk Banten, Kabupaten Serang, Provinsi Banten [Skripsi]. Bogor (Id): Departemen Manajemen Sumberdaya Perairan Fakultas Perikanan Dan Ilmu Kelautan Institut Pertanian Bogor. $91 \mathrm{HIm}$.

Pertiwi, W. (2011). Komposisi Jenis Dan Ukuran Ikan Yang Tertangkap Dengan Sero Dan Pukat Pantaidi Perairan Kota Palopo, Provinsi Sulawesi Selatan.

Pirzan, A. M. (2011). Keragaman Benthos pada Budidaya Rajungan ( Portunus pelagicus ) di Tambak Percobaan Maranak, Balai Riset Perikanan Budidaya Air Payau Maros Sulawesi Selatan. Biosfera, 28(3), 167-175.

Prihatiningsih, P., \& Wagiyo, K. (2017). Sumber Daya Rajungan (Portunus Pelagicus) Di Perairan Tangerang. Bawal Widya Riset Perikanan Tangkap, 2(6), 273. Https://Doi.Org/10.15578/Bawal.2.6.2009.273-282.

Pristya Ningrum, V., Ghofar, A., \& Ain, C. (2015). Beberapa Aspek Biologi Perikanan Rajungan (Portunus Pelagicus) Di Perairan Betahwalang Dan Sekitarnya. Jurnal Saintek Perikanan, 11(1), 62-71. Retrieved From Http://Ejournal.Undip.Ac.Id/Index.Php/Saintek.

Puspito, G. (2011). Umpan efektif danbentuk perangkap plastik dalam menangkap kepiting berenang ( Effective Bait and Plastic Trap Shape in Catching Swimming Crab ), 2(2), $111-119$.

Rejeki, S., Furi, C. A., \& Ariyati, R. W. (2019). Pengaruh Salinitas Yang Berbeda Terhadap Kelulushidupan Dan Pertumbuhan Rajungan (Portunus Pelagicus) Pada Stadia Crab Muda. Pena Akuatika: Jurnal IImiah Perikanan Dan Kelautan, 18(1).

Saenong, M. (2018). Pemetaan Spasial Distribusi Dan Sebaran Rajungan ( Portunus Pelagicus ) Berbasarkan Siklus Hidup Di Perairan Pantai Kabupaten Pangkep, 66-74.

Sains, J., Sains, J., Journal, P., Permatahati, Y. I., \& Sara, L. (2019). Of Fishery Science And 
Buletin JSJ, 2 (2), 2020, 83-92

Available online di: http://ejournal-balitbang.kkp.go.id/index.php/JSJ/index

Innovation Rajungan ( Portunus Pelagicus ) Pada Zona Intertidal Dan Bungin Permai , Konawe Selatan , Sulawesi Tenggara The Relationship Between Carapace Width And Body Weight Of Blue Swimming Crab In Intertidal And Seagrass Zones In, 771, 1-8.

Santoso, D., Raksun, A., . K., \& Japa, L. (2016). Karakteristik Bioekologi Rajungan (Portunus Pelagicus) Di Perairan Dusun Ujung Lombok Timur. Jurnal Biologi Tropis, 16(2), 94105. https://doi.org/10.29303/jbt.v16i2.312

Setiyowati, D. (2016). Kajian Stok Rajungan ( Portunus Pelagicus ) Di Perairan Laut Jawa, Kbupaten Jepara. Jurnal Disportex, 7(1), 84-97. Https://Doi.Org/10.1007/S11262-0171441-3.

Setyawan, H. A., Tangkap, D. P., Diponegoro, U., Soedarto, J. P., Tembalang, K., Indonesia, S., \& Rajungan, S. (2018). Pendugaan Stok Sumberdaya Rajungan Di Perairan Tegal Jawa Tengah, (1), 37-44.

Sulistiono, ., Refiani, S., Tantu, F. Y., \& Muslihuddin, . (2009). Kematangan Gonad Kepiting Kelapa (Birgus Latro) Di Pulau Pasoso, Sulawesi Tengah. Jurnal Akuakultur Indonesia, 8(2), 175-184. Https://Doi.Org/10.19027/Jai.8.175-184.

Susanto, B. (2007). Pertumbuhan, Sintasan Dan Keragaman Zoea Sampai Megalopa Rajungan (Portunus Pelagicus) Melalui Penurunan Sainitas. Perikanan (J.Fish. Sci), (1), 154-160.

Thomas, A. (2017). Analisis Sebaran Lebar Karapas Dan Proporsi Bef (Berried Egg Female) Rajungan, Portunus Pelagicus (Linn, 1758) Yang Tertangkap Di Pantai Timur Lampung.

Triaso, I. (2012). Potensi Dan Peluang Pengembangan Usaha Perikanan Tangkap Di Pantura Jawa Tengah. Jurnal Saintek Perikanan, 8(1). Https://Doi.Org/10.14710/ljfst.8.1.65-73.

Yusfiandayani, R., \& Sobari, M. P. (2011). Di Perairan Teluk Banten ( Bio-Technique Aspect Of Blue Swimming Crab Resources Utilization In Banten Bay Water ), 1(2), 71-80. 